\title{
Improvement in Surface Properties of Ti6Al4V Alloy by ZrN Thin Film
}

\author{
Suresh N. Kadam ${ }^{1^{*}}$, Kailash R. Jagdeo ${ }^{2}$, M. R. Nair ${ }^{3}$ \\ 1. Dept. of Physics, KET's V. G. Vaze College of Arts, Commerce and Science \\ Mithagar Road, Mulund (E) Mumbai (MS)-400081, India. \\ ${ }^{2}$ Dept. of Physics, DSPM's K. V. Pendharkar College, Dombivli (MS), India \\ 3.Principal, Model College, Dombivli (MS), India \\ *E-mail address: snk2122@gmail.com
}

\begin{abstract}
Ti6Al4V alloy is attracting attention as a biomaterial due to its excellent mechanical properties, corrosion resistance and super plasticity. However; this alloy contains aluminium and vanadium liable to do serious harm to human bodies. For overcoming surface originated problems, various surface modification techniques have been used on metallic implants. In this study cathodic arc PVD was used to produce $\mathrm{ZrN}$ coating with different substrate bias voltage at $20 \mathrm{mttor}$ nitrogen gas pressure. Corrosion resistance of Ti6Al4V and $\mathrm{ZrN}$ coated Ti6Al4V were investigated by an electrochemical test, at $37^{\circ} \mathrm{C}$ in normal saline solution. Tafel extrapolation method was used for calculating corrosion rate. ICP-AES studies were carried out to determine amount of ions leached out from samples when kept immersed in normal saline solution. The surface morphology was carried out by XRD. The $\mathrm{ZrN}$ coated samples showed variation in the corrosion resistance with varying voltage and the sample coated at $-200 \mathrm{~V}$ showed an optimum corrosion resistance.
\end{abstract}

Keywords: biomaterials; vacuum cathodic arc PVD; corrosion resistance; micro hardness

\section{INTRODUCTION}

Biomaterials are materials used for making devices that can interact with biological systems to coexist longer service with minimal failure. It is widely recognized that the wear and corrosion of a bio metallic is one of the most important parameters of implant surgery. Due to the optimum properties like corrosion resistance and biocompatibility [1-3], Ti6A14V alloys are widely used in various areas such as artificial hip joints, bone plates, dental implants and aerospace [4-6]. The fundamental requirement of biomaterial is that the material and the tissue environment of the body should be coexisting without having any undesirable or inappropriate effect on each other. Biocompatibility, an essential requirement of any biomaterial, implies the ability of the material to perform effectively with host response for the desired application. Titanium is safe and bio-compatible in many in vitro and vivo studies because it forms a stable $\mathrm{TiO}_{2}$ film which can release titanium particles under the wear in to the body environment. Thus, many attempt to reduce the corrosion, wear processes and better biocompatibility of titanium alloys have been performed by various surface modification 
techniques [7-9]. It has seen that $\mathrm{ZrN}$ coating showed better corrosion resistance then $\mathrm{TiN}$ coating $[10,11]$. Stoichiometry of $\mathrm{ZrN}$ shows only stable phase with a gold-like colour due to its metallic band structure. This coating appears to have substantial potential in aero engine, industrial and biological application [12]. In the present study, $\mathrm{ZrN}$ was coated on Ti6Al4V alloy using cathodic arc physical vapour deposition in order to improve corrosion performance and the surface properties of material.

\section{EXPERIMENTAL METHODS}

\subsection{Sample Preparation}

The Ti6Al4V sheet was cut in small pieces of size $12 \mathrm{~mm}$ X $12 \mathrm{~mm}$. The samples were polished with different silica carbide paper of 302, 800, 1000, 2000 and 2500 grit. The final mirror polish was done using $0.5 \mu \mathrm{m}$ diamond pest in order to produce scratch free mirror polished surface. The polished samples were subsequently cleaned in acetone and deionized water. They are further subjected to ultrasonic cleaning in acetone for 20 minutes, rinsed in deionized water and dried in air. The cathodic arc physical vapour deposition technique was used to produce $\mathrm{ZrN}$ coating on samples with process condition of substrate bias voltages of $50 \mathrm{~V},-200 \mathrm{~V},-350 \mathrm{~V},-500 \mathrm{~V}$ reactive nitrogen gas pressure 20 mtorr; deposition time 20 minutes.

Table 1. Chemical composition wt. \% of Ti6Al4V.

\begin{tabular}{|c|c|c|c|c|c|c|c|c|c|}
\hline $\mathrm{C}$ & $\mathrm{Mn}$ & $\mathrm{Ni}$ & $\mathrm{Mo}$ & $\mathrm{V}$ & $\mathrm{Ti}$ & $\mathrm{N}$ & $\mathrm{Sn}$ & $\mathrm{Fe}$ & $\mathrm{Al}$ \\
\hline 0.036 & $<0.001$ & 0.008 & 0.004 & 4.08 & 89.56 & 0.008 & 0.011 & 0.25 & 5.97 \\
\hline
\end{tabular}

\subsection{Electrochemical Test (Corrosion Test)}

The electrochemical corrosion test was carried out using conventional three- electrode cell of $300 \mathrm{ml}$ capacity by using Gamry-potentiostat/Galvanostat reference 3000, Tafel extrapolation method was used to calculate the corrosion rate. The cell was fitted with working electrode, saturated calomel electrode (SCE) as the reference electrode and the platinum as a counter electrode. The studies were carried out in normal saline solution at $37 \pm 10 \mathrm{C}$ with scan rate $\quad 1 \mathrm{mV} / \mathrm{s}$ and electrode potential was raised from $-800 \mathrm{mV}$ to 1000 $\mathrm{mV}$. The solution was de aerated with pure argon (Ar) gas throughout the experiment. The critical parameters like Ecorr, Icorr, $\beta \mathrm{a}, \beta \mathrm{c}$ and corrosion rate in mpy were calculated from the Tafel plots. 


\subsection{Dissolution Test}

For dissolution test, six samples of bare and $\mathrm{ZrN}$ coated Ti6Al4V alloy of surface area 1 $\mathrm{cm}^{2}$ were immersed in $50 \mathrm{ml}$ of normal saline solution in polypropylene bottles. The bottles were evacuated, tightly closed and incubated in thermostatic chamber at $37 \pm 1{ }^{\circ} \mathrm{C}$. All bottles were shaken and rotated at a speed of $72 \mathrm{rpm}$. At the end of $4^{\text {th }}, 8^{\text {th }}, 16^{\text {th }}$ and 32 weeks solutions were analysed by Inductive Coupled Plasma Atomic Emission Spectroscopy (ICP$\mathrm{AES}$ ) to determine the elemental concentration of $\mathrm{Al}$ and $\mathrm{V}$ leached out from the surface of samples.

\subsection{Surface Morphology}

Microhardness measurement on six samples of bare and $\mathrm{ZrN}$ coated Ti6Al4V alloy were used to calculate the microhardness by mean of a microhardness tester of indenter type Vickers method with test load of $20 \mathrm{gm}$ for 5 seconds and average microhardness was calculated. By means of XRD technique, the different phases present in the film were identified. The average grain size were estimated from full-width at half-maximum (FWHM) of domaninent peaks in XRD patterns by Sherrer formula,

$$
\mathrm{t}=\mathrm{k} \lambda / \beta \cos \theta
$$

Where, $\lambda\left(1.540600 \mathrm{~A}^{0}\right.$ in this case), $\theta$ and $\beta$ are the X-ray wavelength, Bragg diffraction and FWHM in radians respectively.

\section{RESULTS AND DISCUSSION}

\subsection{Corrosion Behaviour}

The corrosion resistance of $\mathrm{ZrN}$ coated Ti6Al4V in normal saline solution was studied and compared with uncoated Ti6Al4V, NiTi and 316L stainless steel. The present studies showed that uncoated 316L stainless steel had lower corrosion rate than NiTi and Ti6Al4V alloy in normal saline solution. The order of corrosion rate obtained, 316L stainless steel < $\mathrm{NiTi}<\mathrm{Ti} 6 \mathrm{Al} 4 \mathrm{~V}$. The ZrN coated sample I showed more improvement in the corrosion resistance than the samples $\mathrm{J}, \mathrm{K}$, and $\mathrm{H}$. The order of corrosion rate obtained, Sample $\mathrm{I}<$ Sample $\mathrm{J}<$ Sample K $<$ Sample H. All the $\mathrm{ZrN}$ coated samples showed low corrosion potential Ecorr, corrosion current density Icorr and corrosion rate than uncoated samples. The sample I show less corrosion rate than all other samples. The substrate bias voltage affects on the corrosion rate shown in Fig.3.

As substrate bias increases corrosion rate decreases sample I shows minimum corrosion rate then all other samples. 


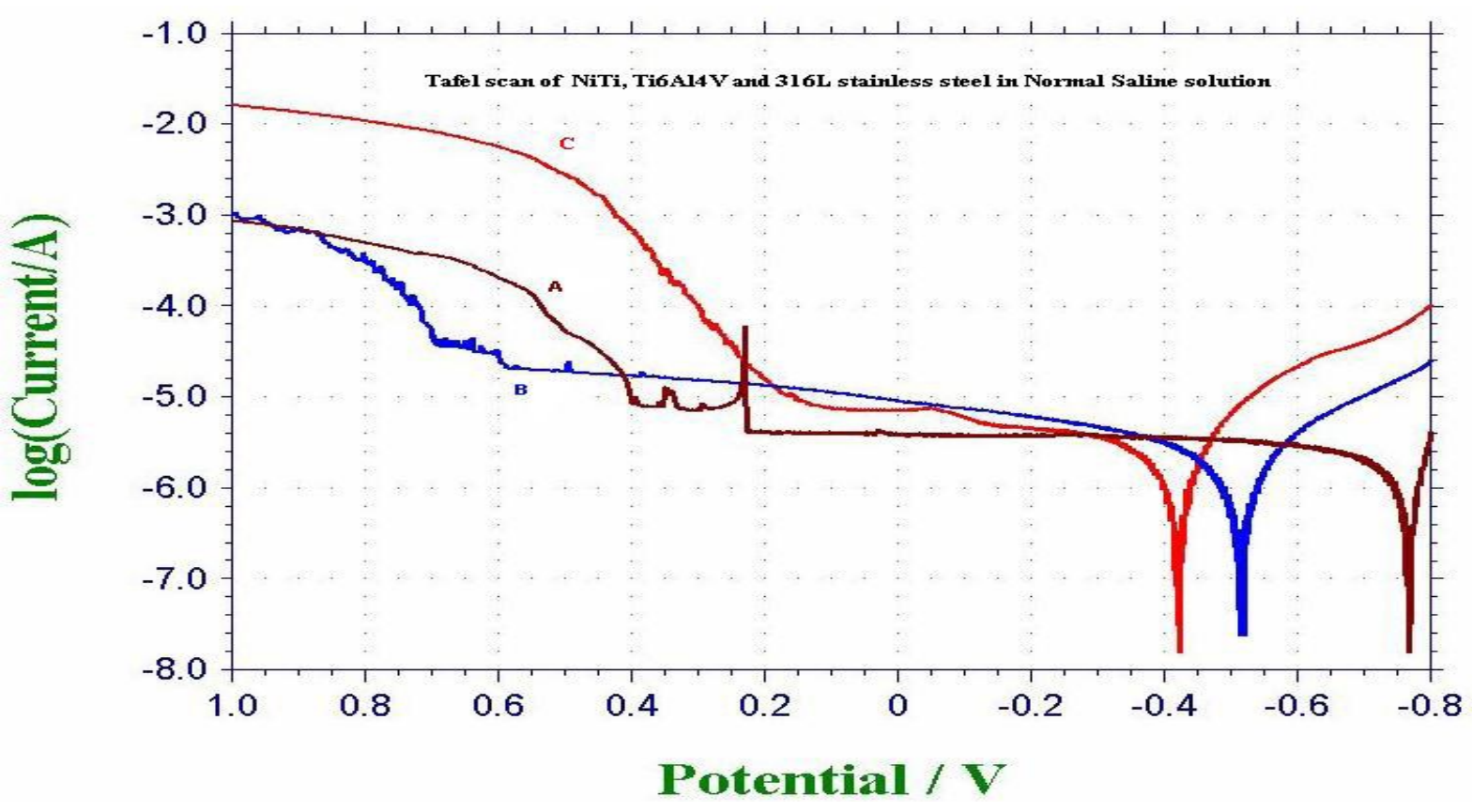

Fig. 1. Corrosion rate of bare Ti6Al4V, NiTi \& 316L by Tafel extrapolation method in normal saline solution.

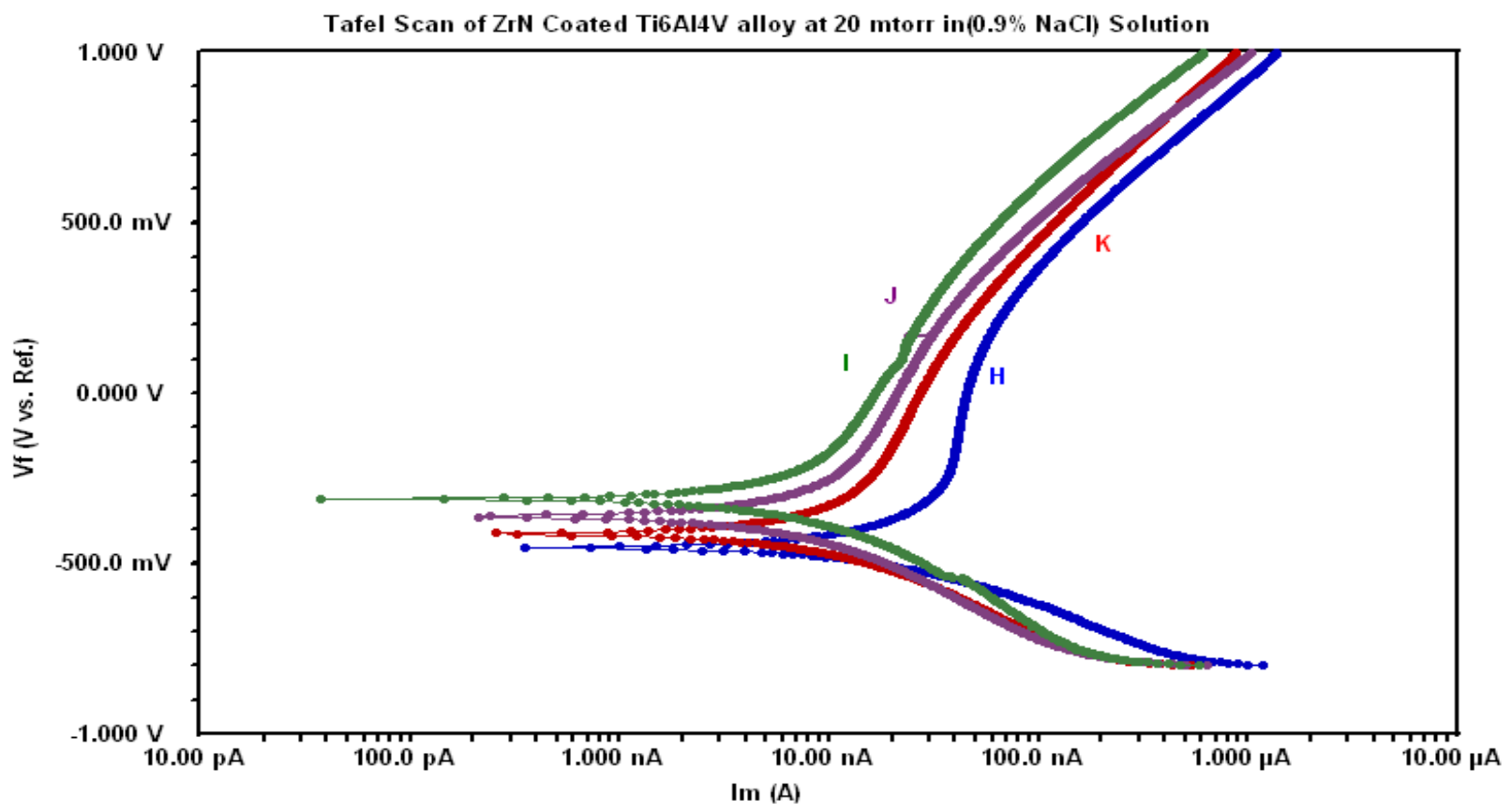

Fig. 2. Corrosion rate of $\mathrm{ZrN}$ coated Ti6Al4V by Tafel extrapolation method in normal saline solution. 
Table 2. Corrosion rate of uncoated and ZrN coated Ti6Al4V by Tafel extrapolation method in normal saline solution.

\begin{tabular}{|c|c|c|c|c|c|c|c|c|}
\hline $\begin{array}{c}\text { Sample } \\
\text { code }\end{array}$ & Sample & $\begin{array}{c}\text { Bias } \\
\text { Voltage }\end{array}$ & Pressure & $\begin{array}{c}\beta_{\mathrm{a}} \\
\text { V/decade }\end{array}$ & $\begin{array}{c}\beta_{\mathrm{c}} \\
\text { V/decade }\end{array}$ & $\begin{array}{c}\mathrm{E}_{\text {corr }} \\
\mathrm{mV}\end{array}$ & $\mathrm{I}_{\text {corr }}$ & $\begin{array}{c}\text { Corrosion Rate } \\
\text { in mpy }\end{array}$ \\
\hline A & Ti6Al4V & -- & -- & -- & -- & -763.0 & $1.603 \mu \mathrm{A}$ & 1.00 \\
\hline B & NiTi & & & & & -512.7 & $1.563 \mu \mathrm{A}$ & 0.82 \\
\hline C & $316 \mathrm{~L} \mathrm{SS}$ & -- & -- & -- & -- & -419.4 & $1.128 \mu \mathrm{A}$ & 0.51 \\
\hline H & Ti6Al4V & $-50 \mathrm{~V}$ & $20 \mathrm{mtorr}$ & 1.323 & $242.9 \mathrm{e}^{-3}$ & -453.1 & $23.26 \mathrm{nA}$ & $15.037 \mathrm{e}^{-3}$ \\
\hline I & Ti6Al4V & $-200 \mathrm{~V}$ & $20 \mathrm{mtorr}$ & 1.114 & $363.8 \mathrm{e}^{-3}$ & -309.1 & $10.81 \mathrm{nA}$ & $6.873 \mathrm{e}^{-3}$ \\
\hline J & Ti6Al4V & $-350 \mathrm{~V}$ & 20 mtorr & 938.8 & $340.6 \mathrm{e}^{-3}$ & -363.0 & $11.22 \mathrm{nA}$ & $7.137 \mathrm{e}^{-3}$ \\
\hline K & Ti6Al4V & $-500 \mathrm{~V}$ & 20 mtorr & 1.092 & $310.5 \mathrm{e}^{-3}$ & -410.8 & $12.18 \mathrm{nA}$ & $7.207^{-3}$ \\
\hline
\end{tabular}

\subsection{Dissolution}

The dissolution test after continuous evaluation at the end of $4^{\text {th }}, 8^{\text {th }}, 16^{\text {th }}$ and 32 weeks using ICP-AES is shown in Fig.4. At every stage of evaluation, uncoated Ti6Al4V showed high amount of $\mathrm{Al}$ and $\mathrm{V}$ leached out from the surface of sample than $\mathrm{ZrN}$ coated Ti6Al4V. The sample I (substrate bias voltage of $-200 \mathrm{~V}$, nitrogen gas pressure $20 \mathrm{mtorr}$ ) showed less amount of $\mathrm{Al}$ and $\mathrm{V}$ ions leached out from the surface of samples then all other samples. $\mathrm{ZrN}$ coating increased the elemental out-diffusion resistance.

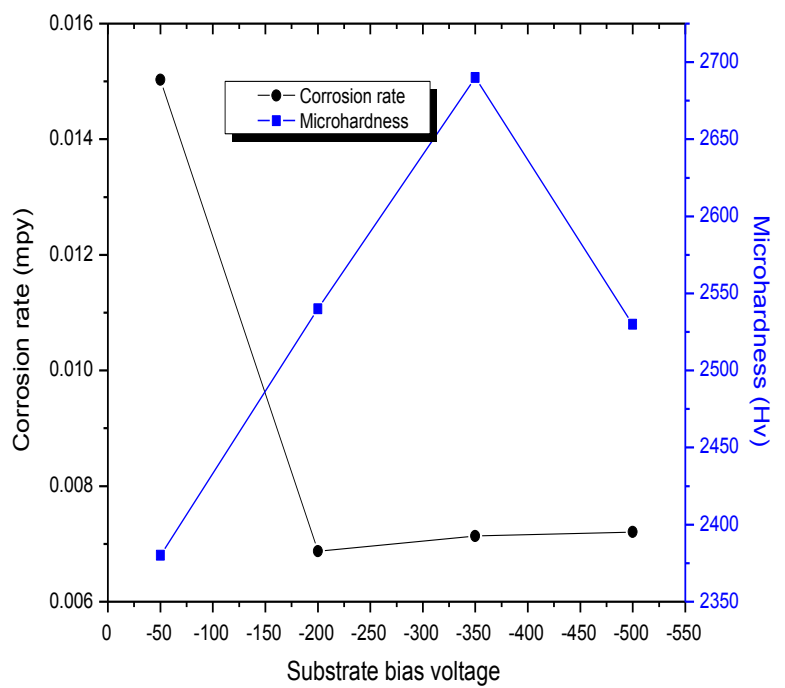

Fig. 3. Corrosion rate and Microhardness of $\mathrm{ZrN}$ coated Ti6Al4V alloy.

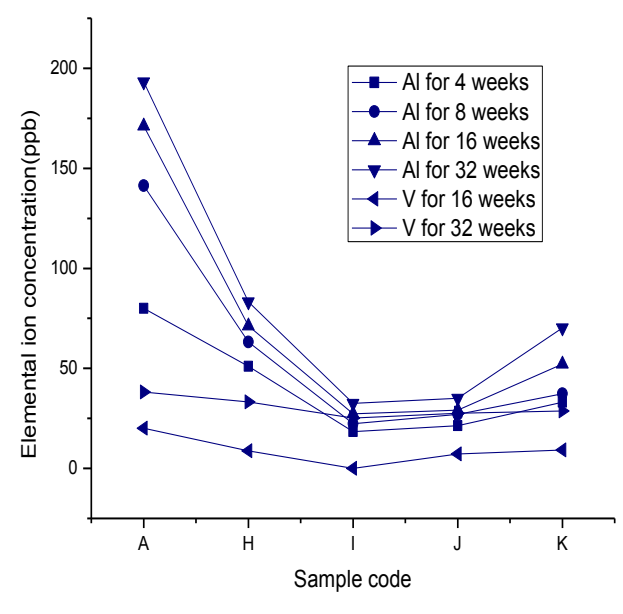

Fig. 4. Dissolution test of $\mathrm{ZrN}$ coated Ti6Al4V in NS solution. 


\subsection{Surface morphology analysis}

Fig.5 shows XRD overlay of uncoated and $\mathrm{ZrN}$ coated Ti6Al4V at nitrogen gas pressure 20 mtorr with different bias voltages. The XRD pattern shows different phases present in the film were identified. The sample $\mathrm{H}(-50 \mathrm{~V}, 20$ mtorr), $\mathrm{ZrN}$ [200] peak is dominant indicating that the preferred orientation is $\mathrm{ZrN}$ [200]. For samples I (-200V, $20 \mathrm{mtorr}), \mathrm{J}(-350 \mathrm{~V}, 20 \mathrm{mtorr}), \mathrm{K}(-500 \mathrm{~V}, 20 \mathrm{mtorr}), \mathrm{ZrN}$ [111] peak is dominant indicating that preferred orientation is $\mathrm{ZrN}$ [111]. The preferred orientation changes from $\mathrm{ZrN}$ [200] to $\mathrm{ZrN}$ [111] with increase in substrate voltage from $-200 \mathrm{~V}$ to $-500 \mathrm{~V}$. The average grain size were estimated from full-width at half-maximum (FWHM) of peaks in XRD patterns by Sherrer formula. The average grain size increases with increase in substrate bias voltages in step of $50 \mathrm{~V},-200 \mathrm{~V},-350 \mathrm{~V}$ but for $-500 \mathrm{~V}$ it decreases. The grain size was found between $14.81 \mathrm{~nm}$ to $15.94 \mathrm{~nm}$. Fig. 3 shows film microhardness increases with increase in bias voltage from $-50 \mathrm{~V}$ to $-350 \mathrm{~V}$ but for substrate bias voltage $-500 \mathrm{~V}$, microhardness of the film decreases. This decrease in grain size and microhardness is due to re-sputtering of $\mathrm{Zr}$ ion from the surface of sample at high bias voltage $-500 \mathrm{~V}$.

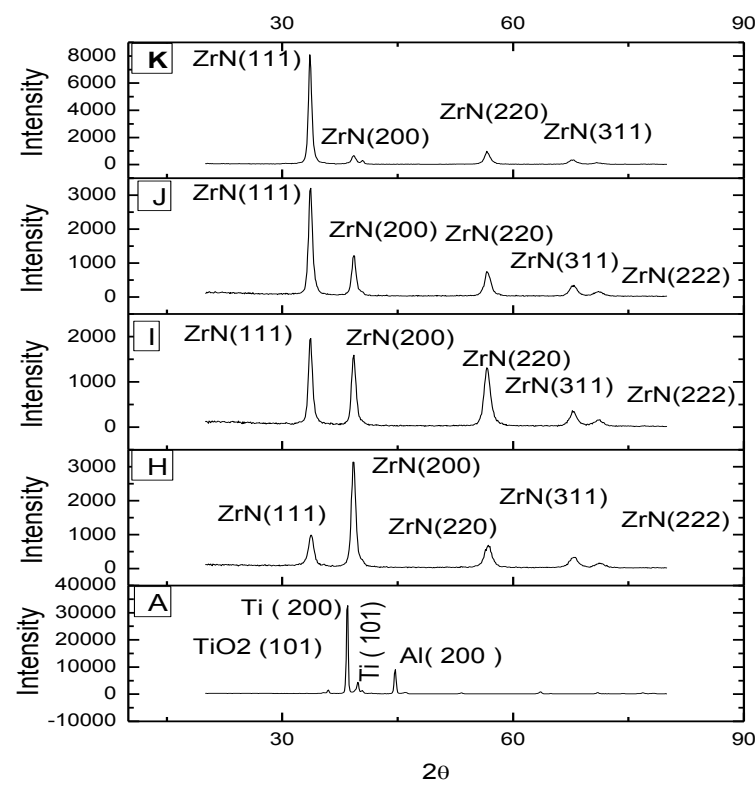

Fig. 5. XRD overlay of uncoated and $\mathrm{ZrN}$ coated Ti6A14V alloy.
Grain size and Microhardness of ZrN coated Ti6Al4V at 20 mtorr

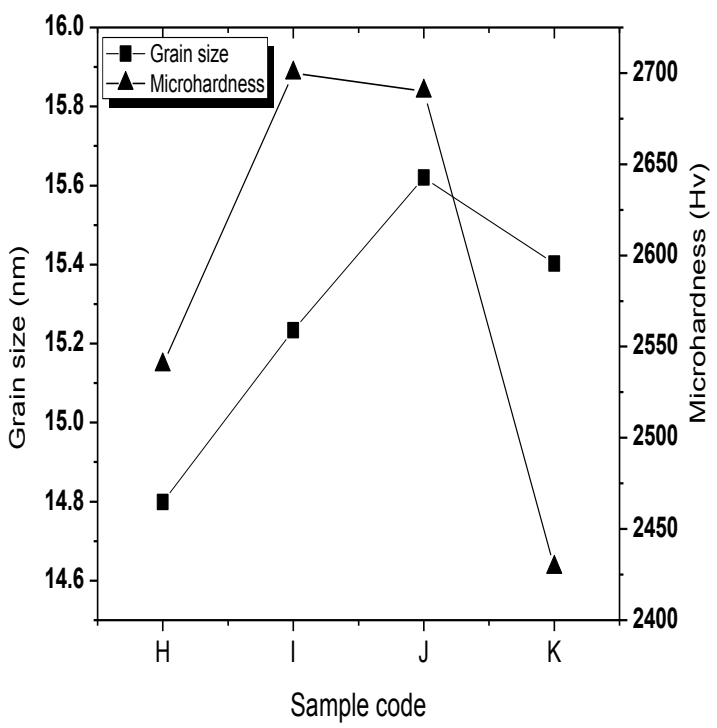

Fig. 6. Grain size and Microhardness of $\mathrm{ZrN}$ coated Ti6Al4V at 20 mtorr.

\section{CONCLUSIONS}

The $\mathrm{ZrN}$ coating increases corrosion resistance, elemental out-diffusion resistance and surface microhardness. XRD showed preferred orientation changes from $\mathrm{ZrN}$ [200] to $\mathrm{ZrN}$ [111] with increase in substrate bias voltage from $-200 \mathrm{~V}$ to $-500 \mathrm{~V}$. The substrate bias voltage affects the corrosion rate, elemental leaching of ions from the surface, microhardness and grain size. The substrate bias voltage $-200 \mathrm{~V}$ at nitrogen gas pressure $20 \mathrm{mtorr}$ is the best coating parameter to improve the surface properties of Ti6AlV alloy. 


\section{References}

[1] M.A. khan, R. L. Williams, Biomaterials 20 (1999), p. 631.

[2] G. J. Wan, N. Huang, Y. X. Leng, P. Yang, J. Y. Chen, J. Wang, and H. Sun, Surf. Coat. Technol.186 (1/2) (2004), p.136.

[3] P. R. Aives, F. A. Santana, L.A. A. Rosa, S. A. Cursion, and E. N. Codaro, Mater. Sci. Engg. C 5 (2004), p. 693.

[4] I. Gurrappa, Mater. Characterization 51 (2/3) (2003), p. 131.

[5] S. Nishiguchi, T. Nakamura, M. Kobayashi, H. M. Kim, F. Miyaji, and T. Kakubo, Biomaterials 20 (5) (1999), p. 491.

[6] M. Al- mayouf, A. A. Al-Swayih, N. A. Al- Mubarak, and A. S. Al-Jabab Mater. Chem. Phys. 86 (2/3) (2004), p. 320.

[7] Racquel Z. Legeros, Ronald G. Craig, J Bone Miner Res. 8 (2) (1993), p. 583.

[8] A. Wisbey, P. J Gregson, L. M. Peter and M. Tuke, Biomaterials 12 (1991), p. 470.

[9] R. G. Vardiman, R. A. Kant, J Applied Physics 53 (1982), p. 690.

[10] R. Hubler, A. Cozza, T. L. Marcondes, R. B. Souza, F. F. Fiori, Surf. Coat.Technol. 142(1)(2001), p.1078.

[11] Wen-Jun Chou, Ge-Ping Yu, Jia-Hong Huang, Surf. Coat. Technol. 167 (1) (2003), p. 59 .

[12] J. A. Sue and H. H. Troue, Surf, Coat. Technol. 39/40 (1989), p. 421. 